\title{
Membaca Peta Dakwah Kota Langsa: Upaya Merumuskan Strategi Dakwah yang Kontributif Bagi Masyarakat
}

\author{
Mawardi Siregar \\ Program Studi Komunikasi dan Penyiaran Islam, IAIN Langsa-Aceh \\ sipirokpbujur76@gmail.com
}

\begin{abstract}
Based on case study in Langsa City, this article examines the map of da'wah and the dynamics of Islamic broadcasting events in Langsa City. Data were collected using observation techniques, in-depth interviews with several muslim preachers and civilian who were selected purposively. Using the concept of da'wah proposed by Sheikh Ali Mahfuz, this article argues that da'wah aims to motivate everyone to do good for improved situation. The findings of this study revealed, the map, which is a description of all the potentials that can be used as directions for da'wah for the success of activities in Langsa City, has not become a serious concern for muslim preachers. On the other hand, the dynamics of da'wah is particularly monotonous. The da'wah method carried out by muslim preacher is stagnantly intertwined with traditional conventional methods, such as lectures. Likewise, the preaching material is intertwined with the issue of the hereafter an sich, which less contributive in solving the problems of the people such as poverty, community empowerment, and environmental problems. Finally, this descriptive research helps muslim preachers to understand the da'wah map of Langsa City, so that the dynamics of da'wah carried out are in accordance to the needs of the target community of da'wah.
\end{abstract}

Keywords: Da'wa map; Da'wa dynamics; Langsa city

\begin{abstract}
Abstrak: Berdasarkan studi kasus di Kota Langsa, tulisan ini membahas tentang peta dakwah dan dinamika kegiatan penyiaran dakwah Islam di Kota Langsa. Data dikumpulkan dengan menggunakan teknik observasi, wawancara mendalam dengan beberapa orang pendakwah maupun masyarakat umum yang dipilih secara purvosif. Dengan menggunakan konsep dakwah yang dikemukakan Syekh Ali Mahfuz, tulisan ini mengajukan argumentasi bahwa dakwah bertujuan untuk memotivasi setiap orang untuk melakukan kebaikan, sehingga terjadi perubahan situasi kearah yang lebih baik. Temuan penelitian ini mengungkap, bahwa peta dakwah yang merupakan gambaran dari seluruh potensi yang dapat dijadikan sebagai arah maupun petunjuk untuk menyukseskan kegiatan dakwah di Kota Langsa, belum menjadi perhatian serius bagi para pendakwah. Sebaliknya, dinamika dakwah terasa sangat monoton. Metode dakwah yang dilakukan pendakwah masih berkelindan pada metode konvensional tradisional, seperti ceramah. Demikian juga dengan materi dakwahnya, berkelindan pada persoalan keakhiratan an sich, sehingga kurang kontributif dalam menjawab permasalahan keumatan seperti persoalan kemiskinan, pemberdayaan masyarakat, dan persoalan lingkungan. Akhirnya, penelitian deskriptif ini membantu para pendakwah untuk memahami peta dakwah Kota Langsa, sehingga dinamika dakwah yang dilakukan adaptif dengan kebutuhan masyarakat sasaran dakwah.
\end{abstract}

Kata Kunci: Peta dakwah; Strategi dakwah; Kota Langsa

\section{PENDAHULUAN}

Dakwah Islam merupakan sarana utama untuk mendidik, membimbing serta membawa manusia menuju kebahagiaan hidup serta menghindari dari keterbelakangan. Kegiatan dakwah dalam Islam sangat penting. Kontiunitas ajaran Islam kata Syekh Ali Mahfuz (1952) dapat bertahan, karena adanya dakwah yang dilakukan oleh pemeluknya. Islam dapat dikenal dan dipahami oleh manusia, karena dakwah. Pandangan tersebut paralel 
dengan adanya perintah Allah Swt terhadap umat Islam, agar terus menyampaikan dakwah secara profesional (QS. Ali Imran 104), sehingga ajaran Islam tetap eksis di permukaan bumi.

Dakwah yang diharapkan tentu tidak hanya sekedar menyeru kepada kebaikan, tetapi berdakwah sekaligus upaya memberikan solusi terhadap permasalahan yang dihadapi oleh umat. Syekh Ali Mahfuz (1952), Al bayayuni (2010), Omar, Sulthon (2003), Mohammad Ali Aziz (2004), dakwah Islam pada hakikatnya bertujuan untuk memberikan solusi terhadap persoalan keumatan, sehingga berubah kearah yang lebih baik sesuai dengan nilai-nilai yang terkandung dalam Al Qur'an dan Hadis. Perubahan yang diharapkan tidak saja pada keimanan yang semakin meningkat, tetapi sekaligus perubahan pada pengetahuan, tindakan dan kualitas hidup.

Tapi tidak dapat dipungkiri bahwa kegiatan dakwah belum kontributif dalam mewujudkan perubahan yang diingikan. Dakwah masih seringkali dipahami sebagai kegiatan yang berkaitan dengan hal-hal yang bersifat eskatologis, sehingga materinya berkelindan pada persoalan halal-haram, sorga-neraka. Sebaliknya, persoalan-persoalan sosial dan dinamika kemasyarakatan kurang mendapat perhatian. Mawardi Siregar (2015) menyebut, bahwa dakwah harus dilakukan secara kontekstual, sesuai dengan kondisi realitas masyarakat, agar dakwah tidak kehilangan elan vital-nya. Istilah Amrullah Achmad (1983), eksistensi dakwah Islam tidak dapat dipisahkan dari realitas yang mengitarinya.

Persoalannya kemudian, bagaimana caranya agar dakwah tidak kehilangan elan vital-nya, atau sebutlah agar kegiatan dakwah selalu kontributif dan solutif dalam menjawab persoalan keumatan? Menjawab pertanyaan tersebut, tentu tidak terlepas pada pemahaman para pendakwah terhadap peta dakwah yang tersedia. Peta dakwah adalah berupa gambaran dari keseluruhan potensi yang dapat dimanfaatkan untuk mendukung suksesnya kegiatan dakwah. Mengutip istilah Abdullah (2012), Aziz (2015), demikian juga Yakin (2020), mereka menyebut peta dakwah sebagai gambaran realitas sosial masyarakat yang dijadikan sebagai informasi untuk melaksanakan dakwah. Dengan demikian, peta dakwah menjadi petunjuk atau dapat dikatakan sebagai modal utama bagi para pendakwah untuk melaksanakan dakwah yang tepat guna. Peta dakwah meliputi seluruh unsur yang terkait dengan kegiatan dakwah itu sendiri, mulai dari da'i, mad'uw, media, pesan, metode dan tujuan yang diinginkan.

Perlu ditegaskan, bahwa tulisan ini bukanlah satu-satunya hasil penelitian yang membincangkan tentang peta dakwah dan dinamikanya. Sejumlah kajian dengan tema yang hampir sama pernah dilakukan oleh para sarjana. Antara lain, Nihayah dan Burhanuddin (2018) mengkaji pemetaan potensi dakwah yang diharapkan dapat membantu pendakwah untuk menyampaikan ajaran Islam di Kelurahan Lemahwungkuk Kota Cirebon. Abdullah (2012) juga menulis pentingnya analisis peta dakwah dalam merumuskan keterukuran keberhasilan dakwah. Azis (2015) menulis pentingnya peta dakwah, agar dakwah secara metodologis dan praktis dapat berkontribusi dalam memenuhi kebutuhan umat terhadap ajaran agama. Pimay dan Savitri (2021) menulis pentingnya memahami dinamika dakwah di era modern, sehingga dakwah yang dilakukan lebih terarah dalam mengantisipasi kecenderungan masyarakat modern. 
Sejumlah kajian dakwah yang telah disebutkan, pada prinsipnya membincangkan bahwa dakwah merupakan aktivitas keagamaan yang bertujuan untuk mewujudkan masyarakat yang mengamalkan ajaran Islam. Selain untuk menguatkan pandangan para pengkaji yang telah disebutkan, maka arti penting dari hadirnya tulisan ini adalah untuk menunjukkan bahwa selain untuk mewujudkan masyarakat yang mengamalkan ajaran agama, dakwah juga merupakan kegiatan yang bertujuan untuk memotivasi sasaran dakwah dalam mewujudkan kesejahteraan dunianya. Ini sejalan dengan pandangan Syekh Ali Mahfuz (1952), bahwa dakwah tidak hanya membincangkan persoalan eskatologis, tetapi sekaligus membincangkan kesejahteraan dunia. Kesejahteraan dunia hanya akan dapat diwujudkan, jika dakwah diposisikan dan dipahami sebagai aktivitas yang diperuntukkan untuk memberikan solusi terhadap masalah ummat. Tidak hanya masalah yang berkaitan dengan keagamaan, tetapi termasuk masalah di luar agama, seperti masalah sosial, politik, ekonomi, kemiskinan, kelestarian lingkungan, pendidikan, pertanian dan sebagainya. Dinamika dakwah yang adaptif dan solutif hanya dapat dilakukan, jika kegiatan dakwah dilaksanakan sesuai dengan peta dakwah.

\section{METODE PENELITIAN}

Penelitian kualitatif dipilih sebagai metode pada penelitian ini karena tujuannya untuk mendeskripsikan secara sistematis fenomena yang diamati dan seluruh kondisi ril fakta-fakta di lapangan (Creswell, 1994; Erickson, 2018; Lincoln \& Guba, 1985; Mulyana, 2004). Sebagaimana yang berlaku pada penelitian kualitatif, data penelitian ini dikumpulkan melalui teknik observasi dan wawancara mendalam dengan informan kunci (key informan) (Bungin, 2003). Informan kunci ditetapkan dengan menggunakan teknik purvosive sampling mewakili para pendakwah di Kota Langsa.

Observasi dilakukan berulang-ulang untuk melihat aktivitas dakwah yang dilakukan para pendakwah di Kota Langsa, sehingga diperoleh informasi tentang pemahaman mereka terhadap peta dakwah Kota Langsa. Wawancara mendalam (in depth interview) dilakukan dengan para informan sehingga diketahui secara pasti tentang dinamika penyiaran dakwah Islam di Kota Langsa, dan juga diketahui secara keseluruhan kemampuan pendakwah dalam memanfaatkan peta dakwah.

Pada akhirnya, seluruh data yang sudah dikumpulkan dianalisis dengan menggunakan teknik analisis interaktif Miles dan Huberman (1992) yang dimulai dari reduksi data, penyajian dan penarikan kesimpulan. Data dideskripsikan secara mendalam (thick description) (Geertz, 1973), setelah melalui proses validasi yang dilakukan dengan teknik triangulasi (Moleong, 2006).

\section{HASIL PENELITIAN DAN PEMBAHASAN}

\section{Peta Dakwah Islam Kota Langsa}

Kota Langsa adalah hasil pemekaran Kabupaten Aceh Timur yang disahkan berdasarkan Undang-Undang No. 3 tahun 2001. Diresmikan oleh Menteri Dalam Negeri atas nama Presiden Republik Indonesia tanggal 17 Oktober 2001. Pada awalnya terdiri dari 
dua kecamatan, dan seiring dengan perkembangannya yang cukup pesat, dimekarkan menjadi lima kecamatan.

\section{Gambar 1. Peta Administrasi Kota Langsa}

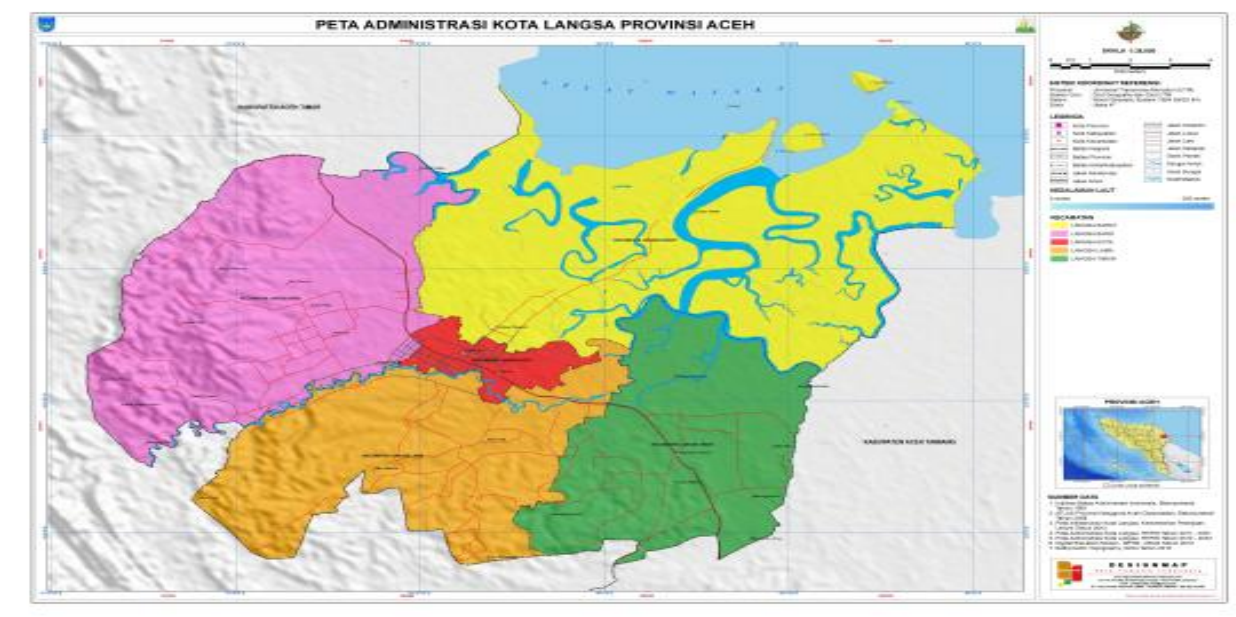

Kota Langsa terdiri dari 5 kecamatan dan 66 wilayah kelurahan/desa. Jumlah penduduknya sebanyak 176811 jiwa, terdiri dari 87719 jiwa laki-laki dan 89092 jiwa perempuan. Masyarakat Kota Langsa umumnya hidup di daerah perkotaan dengan mata pencaharian sebagai buruh, karyawan pegawai, pedagang dan sebahagian kecil tinggal di pedesaan dengan pekerjaan sebagai petani dan buruh tani. Tingkat pendapatan masyarakat Kota Langsa juga sangat variatif sesuai dengan jenis pekerjaan yang ditekuni, sehingga berdampak pada pendapatan perkapita masyarakat. Kemiskinan juga masih menjadi isu yang belum dapat dituntaskan oleh Pemerintah Kota Langsa (Langsa, 2020).

Kondisi keagamaan masyarakat Kota Langsa sangat heterogen, terdiri dari agama Islam sebagai agama mayoritas penduduknya. Selain itu, ada penganut agama Kristen dan juga Hindu yang masing-masing memiliki fasilitas ibadah yang tediri dari 62 masjid, 120 musalla, 1 gereja dan 1 vihara. Keragaman agama masyarakat Kota Langsa berpadu dengan kesukuan yang variatif juga. Kota Langsa memiliki kekayaan etnis dan budaya, antara lain suku Aceh sebagai mayoritas, suku Jawa, suku Tamiang dan juga suku Batak Karo dan Mandailing.

Aktivitas keagamaan yang dilakukan oleh masing-masing pemeluknya turut memperkuat karaktristik Kota Langsa yang menghargai hamoni dan kedamaian. Meskipun nuansa religius keislaman sangat terasakan ditengah-tengah masyarakat, namun situasi tersebut tidak sampai mengganggu aktivitas keagamaan umat lainnya. Dalam keseharian masyarakat, agama menjadi spirit untuk menciptakan kebaikan-kebaikan, sehingga masyarakat Kota Langsa dikenal sangat religius. Religiusitas sebagaimana ditulis Holdcroft (2006) selalu diperlihatkan seseorang melalui tindakan nyata dalam pengamalan agama kesehariannya. Mengutip istilah Glock dan Stark (1968), indikator religiusitas terlihat dari ketaatan dalam menjalankan kegiatan ritual, keyakinannya pada kebenaran agama, dan pengetahuan agama yang diaplikasikan dalam setiap pengalaman. 
Masyarakat Kota Langsa adalah masyarakat religius yang menerapkan pelaksanaan syariat Islam. Pemeluk agama hidup damai berdampingan dan beribadah secara aman dan merdeka sesuai dengan keyakinan masing-masing. Bagi umat Islam, masjid dan musalla tidak hanya sekedar tempat peribadatan, tetapi sekaligus tempat berinteraksi. Masyarakat membangun tempat-tempat ibadah secara swadaya, karena didasari oleh keyakinan bahwa infak dan sedekah sebagai penolong di kemudian hari. Keyakinan tersebut diperkuat oleh pandangan para ulama, tengku dan para pendakwah yang menjadikan masjid sebagai pusat penyebaran dakwah Islam. Masjid dan mushala merupakan bahagian yang tidak terpisahkan dari aktivitas keagamaan masyarakat. Dapat dikatakan, bahwa masjid menjadi cerminan keberagamaan dan religiusitas masyarakat.

Heteroginitas masyarakat Kota Langsa, tidak menghalangi pengamalan syariat dan juga kegiatan dakwah. Bahkan Mawardi Siregar (2019) mencatat dalam penelitiannya, kota Langsa menjadi kota percontohan dalam penerapan syariat Islam di Aceh. Kondisi ini menguatkan argumentasi, bahwa agama tidak selalu berkontribusi terhadap terjadinya konflik antarumat beragama. Agama mengajarkan keadaban dan kedamaian yang membuat pemeluknya menjadi dapat hidup dalam harmoni dan kedamain, jika agama dipelajari dan diamalkan secara benar. Sebagaimana pandangan yang disampaikan Komaruddin Hidayat (1998), bahwa agama menjadi satu keyakinan dan sumber nilai yang mampu menjadi kekuatan untuk membangun masyarakat beradab dan berbudaya.

Gambaran di atas mengukuhkan argumentasi, bahwa keragaman potensi yang dimiliki oleh masyarakat, baik keragaman agama, suku, pendidikan dan juga ekonomi, menjadi kekuatan sekaligus ancaman terhadap keutuhan satu bangsa. Jika salah dalam mengelolanya, akan menjadi ancaman. Sebaliknya, jika benar dalam mengelolanya, maka akan menjadi potensi dalam menjaga kedamaian. Selain ingin mewujudkan masyarakat yang religius, Pemerintah Kota Langsa juga bercita-cita untuk mewujudkan kedamaian dalam keragaman (Siregar, 2019).

Potensi dan permasalahan yang telah dijelaskan di atas, menjadi data yang sangat penting bagi para pendakwah untuk merumuskan peta dakwah, sehingga dakwah yang dilakukan lebih adaptif dalam memberikan solusi terhadap persoalan yang dihadapi masyarakat yang terus berkembang dinamis. Pembuatan peta dakwah sangat penting dalam mendukung keberhasilan pelaksanaan kegiatan dakwah. Peta dakwah merupakan gambaran dari keseluruhan kondisi sosio demografi masyarakat yang menjadi sasaran dakwah. Dengan adanya peta dakwah kata Syukur Kholil (2010), pelaksanaan kegiatan dakwah akan lebih terukur keberhasilannya, karena dakwah dilaksanakan sesuai dengan data.

Membaca peta dakwah, menuntut agar para pendakwah bersifat partisipatif dan perlu menggagas dakwah pemberdayaan. Seperti yang ditulis oleh Hemmerling (2020), bahwa pemetaan potensi masyarakat dan melibatkan mereka dalam program yang sudah dicanangkan sangat penting dilakukan untuk mendukung tercapainya tujuan yang diinginkan. Paralel dengan itu, dakwah tepat guna dan kontributif terhadap persoalan umat harus mempertimbangkan potensi yang ada. Sebagaimana ditulis Abdullah (2012), bahwa dakwah yang dilakukan selama ini kurang kontributif karena peta dakwah yang belum konkrit. 
Dengan demikian, para pendakwah tidak boleh bertindak seolah-oleh sebagai seorang yang paling mengetahui dan merasa harus lebih dimuliakan. Para pendakwah harus mampu membaca potensi lokal dan memanfaatkannya dengan cara melibatkan dan memberdayakan seluruh elemen untuk mencapai tujuan dakwah. Maka pemetaan kondisi masyarakat sebagaimana yang dicatat oleh Vavilina (2015) merupakan satu langkah strategis yang harus ditempuh untuk menjadikan program atau kegiatan lebih berdaya guna.

\section{Strategi Dakwah yang Kontributif Bagi Masyarakat Kota Langsa}

Pada hakikatnya dakwah merupakan aktivitas yang bertujuan untuk merubah masyarakat kearah yang lebih baik berdasarkan Alquran dan Hadis. Perubahan yang dikehendaki meliputi seluruh aspek kehidupan, mulai dari peningkatan keimanan, pengetahuan, amal saleh dan peningkatan kualitas hidup. Peningkatan aspek-aspek tersebut dapat tercapai jika kegiatan dakwah dilakukan secara terprogram, berkesinambungan dan memiliki strategi yang sesuai dengan kebutuhan masyarakat.

Mencerdasi kondisi realitas masyarakat yang syarat dengan kompleksitas permasalahan, maka sangat penting merumuskan dakwah yang kontributif. Dakwah yang kontributif berarti dakwah yang mampu memberikan perubahan terhadap kondisi masyarakat sasaran dakwah. Tidak hanya memberikan perubahan terhadap peningkatan pemahaman agama an sich, tetapi memberikan solusi juga terhadap persosalan pendidikan, kemiskinan, lingkungan hidup, dan aspek-aspek kehidupan lainnya Merumuskan dakwah yang kontributif, tidak terlepas dari strategi dakwah yang diterapkan dan strategi dakwah berkaitan dengan kondisi sosio kultural, sosio demografi, dan sosio religius masyarakat sasaran dakwah. Istilahnya dalam kajian komunikasi, bahwa untuk mengkomunikasikan pesan kepada khalayak, sangat penting mempertimbangkan sistem dan dinamika sosial yang berlaku pada masyarakat yang menjadi sasaran penyampaian pesan (Effendy, 1984; Rachmadi, 1990).

Konritnya, untuk merumuskan dakwah yang kontributif berkaitan erat dengan situasi dan kondisi dimana dakwah itu disebarkan. Abdul Karim (2021) menyebut, bahwa rumusan strategi dakwah sifatnya sangat kondisional sesuai dengan potensi yang dimiliki oleh masing-masing wilayah dimana dakwah itu dilakukan. Dalam kajian komunikasi, Arifin (2003) juga menyebutkan bahwa strategi dipilih bedasarkan situasi dan kondisi yang dihadapi oleh komunikator. Dengan demikian, dakwah sebagai upaya mengkomunikasikan ajaran Islam kepada masyarakat, harus memiliki strategi agar pesan dakwah tepat guna.

Merumuskan strategi dakwah yang kontributif bagi masyarakat Kota Langsa tidak terlepas dari realitas sosial sebagaimana yang digambarkan pada peta dakwah Kota Langsa. Selanjutnya, rumusan strategi dakwah dapat dimulai dari memperhatikan unsur-unsur dakwah, yaitu da'i, mad'u, pesan, media, metode dan tujuan.

\section{Da'i}

Berdasarkan data yang diperoleh, da'i di Kota Langsa dikategorikan kepada dua macam, yaitu dakwah yang dilakukan secara perorangan dan dilakukan secara kelembagaan. Secara perorangan, da'i berdakwah atas nama pribadi dan dakwah yang dilembagakan, da'i berdakwah mewakili lembaga tempat bernaungnya. Selain da'i yang 
bernaung di bawah Dinas Syariat Islam, terdapat sejumlah organisasi kemasyarakatan Islam yang dijadikan para da'i sebagai tempat bernaung. Antara lain, NU, Muhammadiyah, Al Wasliyah, Ikatan Da'i Indonesia (IKADI), ICMI dan BKPRMI. Bahkan ada yang lembaga yang mengkhususkan kajian seperti TASTAFI (Tasawuf, Tauhid dan Fiqh), Al Maidah forum kajian keagamaan Kota Langsa, Assunni forum kajian keagamaan Kota Langsa.

Kehadiran sejumlah lembaga tersebut diharapkan dapat mendorong semakin terjawabnya persoalan masyarakat Muslim Kota Langsa. Tidak hanya pesoalan yang berkaitan dengan keagamaan, tetapi termasuk persoalan lainnya. Sebagaimana disebutkan Zulkarnain yang merupakan salah satu tokoh agama dan Ketua MPU Kota periode 20142019;

Dalam pandangan saya, kehadiran sejumlah organisasi Islam di Kota Langsa sangat diharapkan, terutama dalam mewujudkan masyarakat yang bersyariat Islam. Saya melihat hampir semua kegiatan dakwah organisasi Islam di Kota Langsa hidup. Para ulama dayahpun turut mendukung penyiaran dakwah di Kota Langsa dengan cara keluar dari dayahnya ke masyarakat. Namun yang diharapkan juga, tentu organisasiorganisasi keislaman harus terus meningkatkan kompetensi para pendakwahnya agar lebih mampu mengatasi persoalan masyarakat yang semakin kompleks. Selain menguasai ilmu agama, para pendakwah perlu juga menguasai berbagai disiplin ilmu lain yang berkaitan dengan pelaksanaan dakwah agar dakwah yang dilakukan relevan dengan perkembangan zaman (Hasil Wawancara, 2019).

Paralel dengan informasi yang disampaikan, kehadiran organisasi keagamaan Islam di Kota Langsa diharapkan dapat menjadi ujung tombak pembinaan para da'i, sehingga lahirlah da'i-da'i profesional. Namun kenyataannya, masih banyak da'i pendakwah yang belum mampu membaca peta dakwah Kota Langsa, sehingga dakwah yang dilakukan belum berorientasi pada kebutuhan masyarakat. Sebagaimana disampaikan Supardi;

Sebenarnya pengetahuan agama saya sangat minim, karena sekolah sayapun hanya tamat SMP. Saya hanya belajar agama di balai-balai yang ada di gampong (desa). Bukan saya tidak mau menghadiri ceramah-ceramah yang diadakan di masjid. Tetapi saya perhatikan, tengku-tengku hanya berceramah tentang shalat, zakat dan masalah kemiskinan, tetapi tidak memberikan solusi untuk mengatasi kemiskinan itu. Kalau hanya demikian saja, sangat mudah menjadi ustaz itu. Sedikit menghafal ayat dan hadis untuk modal yang akan disampaikan ke masyarakat dan mampu berbicara, sudah jadi ustaz (Hasil Wawancara, 2019).

Informasi di atas merupakan sebentuk ketidaktertarikan mad'u terhadap dakwah yang disampaikan, sekaligus menunjukkan dakwah belum berkontribusi terhadap persoalan masyarakat. Informasi tersebut menguatkan argumentasi pentingnya melakukan pembinaan da'i secara berkesinambungan. Da'i yang diharapkan tentu tidak hanya sekedar mampu berceramah menyampaikan ajaran Islam, tetapi sekaligus memiliki pengetahuan, keahlian dan pengalaman dalam membaca kondisi sosio-psikologis dan sosil kultural masyarakat sasaran dakwah. Kemampuan yang demikian disebut dengan kredibilitas dan kredibilitas berkaitan dengan kegiatan dakwah. Sebagaimana yang ditulis Hariyanto (2020), bahwa tercapainya tujuan dakwah sangat erat kaitannya dengan kredibilitas pendakwah. 
Aristoteles menyebut tiga syarat agar komunikator disebut dengan kredibel, yaitu dalam dirinya terintegrasi tiga kekuatan yaitu ethos, pathos dan logos. Aristoteles menggambarkan hirarki ketiganya seperti segi tiga sama kaki yang sama-sama penting.

Gambar 2. Hirarki ethos, pathos, logos Aristoteles.

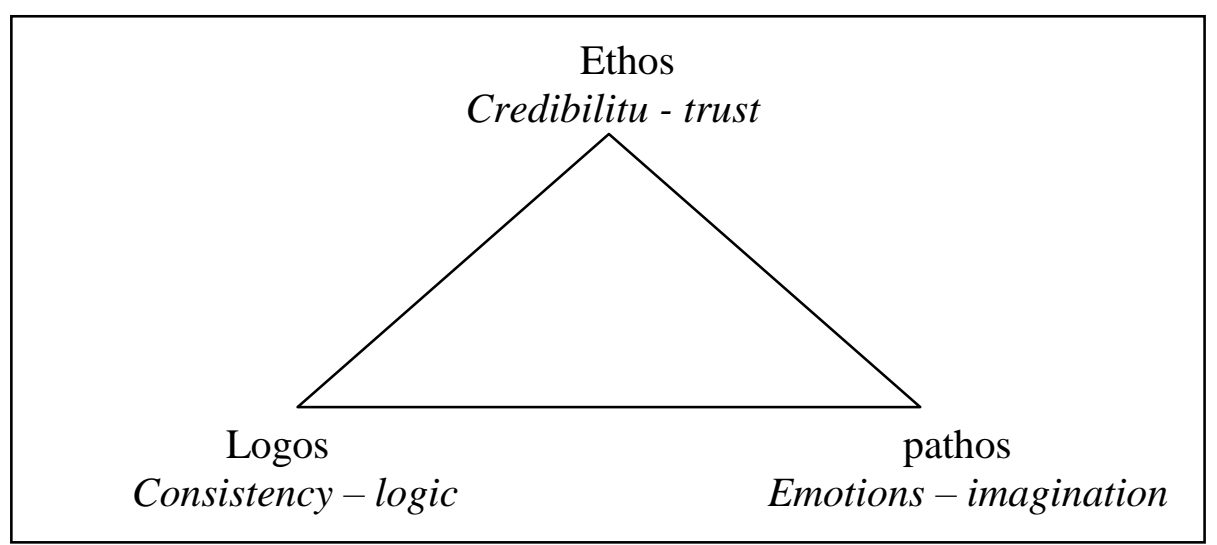

Dimensi ethos, pathos dan logos merupakan kesatuan yang tidak dapat dipisahkan dalam segitiga komunikasi. Etos menyangkut karakter kepribadian komunikator, pathos adalah kemampuan membangun ikatan emosional dan logos merupakan kemampuan merasionalisasi sesuatu, sehingga berterima pada akal pikiran. Semua unsur tersebut kata Effendy akan menyatu pada diri seorang komunikator, jika komunikator memiliki kesiapan, kesungguhan, ketulusan, kepercayaan, ketenangan, keramahan, dan kesederhanaan (Effendy, 2001).

\section{Mad'u}

Mad'u (sasaran yang dijadikan sebagai objek dakwah) adalah seluruh manusia. Dari sudut pandang keagamaan, mad'u terdiri dari orang yang sudah menerima Islam, belum berislam atau sama sekali hanya beragama atas keyakinan yang turun temurun dari nenek moyang mereka, seperti agama Parmalim pada masyarakat Batak Toba (Katimin, 2012). Dari suduh kajian sosiologisnya, mad'u terdiri dari masyarakat desa, masyarakat kota dan bahkan masyarakat terisolir yang tingkat pemahaman agamanya berbeda, demikian juga dengan tingkat ekonomi, dan profesi yang berbeda-beda (M. Arifin, 2004).

Dari sudut pandang demografisnya, mad'u di Kota Langsa dapat dikategorikan menjadi dua macam, yaitu masyarakat desa dan masyarakat kota. Semarak dakwah pada dua kelompok ini terlihat sangat berbeda dari frekuensi pelaksanaannya. Semarak dakwah di pedesaan sangat tidak ekuvalen bila dibandingkan dengan semaraknya dakwah di perkotaan. Sebaliknya, para pendakwah lebih cenderung memilih berdakwah di kota dari pada ke desa-desa karena berdakwah di perkotaan, secara finansial lebih menggiurkan dibandingkan di pedesaan.

Mad'u yang menjadi sasaran dakwah bukan masyarakat yang vakum, melainkan bergerak dinamis sesuai dengan perkembangan zaman. Dengan demikian, hampir dapat dipastikan bahwa persoalan yang dihadapi mad'u pun akan lebih kompleks dan perubahan yang mereka hadapipun jauh lebih dinamis. Dalam konteks masyarakat yang terus berkembang, para pendakwah harus memastikan bahwa ajaran Islam harus bernar-benar dapat dirasakan sebagai rahmat. Kerahmatan Islam ditunjukkan melalui dakwah yang dapat 
membantu mad'u keluar dari permasalahannya.

Mencermati heteroginitas mad'u dari perspektif demografisnya, menjadi modal utama bagi pendakwah untuk memilih strategi dakwah yang tepat. Jika selama ini kerahmatan Islam belum sepenuhnya menyentuh segi-segi kehidupan mad'u, terutama yang tinggal di pedesaaan, maka perlu dirumuskan dakwah yang merata dan berimbang antara dakwah di perkotaan dengan dakwah di pedesaan, sehingga masyarakat di pedesaanpun dapat menikmati dakwah sebagaimana layaknya yang dirasakan masyarakat kota. Untuk mengatasi kesenjangan dakwah, mad'u juga dituntut agar lebih kreatif mencari sumbersumber informasi keagamaan yang dapat mendukung peningkatan pengetahuan dan keimanannya. Mad'u misalnya dapat mengakses dakwah dari berbagai sumber informasi yang tersedia, seperti televisi, internet, media sosial dan sebagainya.

Ketersediaan fasilitas internet gratis bagi masyarakat di pedesaan tentu dibutuhkan untuk mendukung semakin mudahnya masyarakat melakukan aksesibilitas terhadap informasi keagamaan. Kehadiran internet dapat mendorong peningkatan pengetahuan masyarakat desa, karena secara perlahan masyarakat akan menjadi bahagian dari masyarakat yang melek informasi dan teknologi. Sebagaimana ditulis oleh Roztocki (2019), bahwa ketersediaan teknologi informasi komunikasi dapat mendukung pembangunan ekonomi, sosial masyarakat. Badri (2016) juga menyebutkan bahwa masyarakat desa mengalami perubahan yang sangat drastis atas bantuan digitalisasi teknologi informasi.

\section{Pesan}

Pesan dakwah yang ditujukan kepada masyarakat sasaran dakwah tentu juga sangat kondisional. Akan sangat berbeda pesan dakwah yang disampaikakan kepada masyarakat kota dengan masyarakat desa. Itulah sebabnya, merumuskan pesan dakwah amat sangat penting dan perumusan pesan dakwah juga sangat penting didasarkan pada kondisi peta dakwah. Jika pesan dakwah yang disampaikan mudah dipahami, sesuai dengan kebutuhan mad'u, tentu akan lebih kontributif dan lebih mudah mempengaruhi mad'u, dibandingkan dengan pesan dakwah yang tidak dirumuskan sebelumnya.

Secara makro pesan dakwah terbagi kepada empat, yaitu meliputi akidah (tauhid), syariah (hukum), akhlak dan muamalah (interaksi sosial). Tetapi para pendakwah juga perlu keluar dari tataran makro tersebut kepada tataran mikro, untuk melihat persoalan mad'u secara lebih spesifik. Pendakwah tidak boleh melihat persoalan dari menara gading, lantas menjeneralisasi dan menganggap semua permasalahan mad'u sama. Realitatas inilah yang terjadi pada pendakwah di Kota Langsa sehingga pesan-pesan yang disampaikan kurang kontributif dalam menjawab persoalan mad'u. Pesan-pesan dakwah berkutat pada persoalan makro, padahal banyak persoalan-persoalan mad'u yang harus dilihat dari konteks yang lebih mikro. Misalnya, persoalan pendidikan anak, kemiskinan, kebersihan, pelestarian lingkungan hidup, pemberdayaan ekonomi dan sebagainya. Tentu persoalanpersoalan ini harus dilihat sebagai masalah penting, sehingga pesan-pesan dakwah dapat disesuaikan.

Nabi Muhammad Saw sebagai suri tauldan bagi para pendakwah, pesan dakwahnya tidak hanya mengurusi persoalan keagamaan. Justerus muatan-muatan ceramahnya mencakup berbagai aspek, selain aspek keagamaan, seperti perbaikan kehidupan sosial, 
politik, ekonomi, pertanian, peternakan, perdagangan, penghargaan terhadap alam dan sebagainya. Pemilihan pesan, tentu dikaitkan dengan konteks masyarakat yang menjadi sasaran dakwah.

\section{Media}

Media merupakan wadah maupun saluran yang digunakan untuk menyampaikan pesan dakwah kepada masyarakat. Media dakwah sangat penting diperhatikan oleh da'i, jika dakwahnya ingin berhasil guna. Mencermati kondisi ril Kota Langsa, terdapat sejumlah media yang dapat digunakan untuk menyampaikan pesan-pesan dakwah. Selain media modern, seperti surat kabar, televise, radio, dan juga media sosial, terdapat juga media tradisional yang masih hidup sebagai kearifal lokal yang terus dipelihara masyarakat sebagai media penyebaran informasi, seperti tari seudati dan tari saman. Dua kesenian ini sangat akrab dengan masyarakat Kota Langsa dan keduanya memuat syair-syair keagamaan yang memiliki nilai-nilai dakwah. Meskipun masyarakat sudah terbiasa dengan suguhan informasi melalui media modern, tetapi keberadaan media tradisional juga akan tetap relevan dijadikan sebagai media informasi. Keduanya merupakan dua unsur yang saling melengkapi dalam praktik penyampaian informasi kepada masyarakat. Seperti yang disebutkan Laila (2015), bahwa media tradisional tidak dapat dinafikan dari praktik penyebaran informasi kepada masyarakat, meskipun teknologi informasi mengalami perkembangan yang pesat.

Strategi mewujudkan dakwah yang adaptif dan kontributif dapat dilakukan dengan memanfaatkan potensi ketersediaan media. Jika da'i dalah menggunakan media, bisa jadi pesan dakwah tidak akan efektif dan efisien. Selain media modern, perlu juga para pendakwah menguasai penggunaan media-media tradisional sebagai bagian dari penyebaran dakwah Islam. Hal tersebut menjadi penting, karena media tradisional tidak hanya sekedar sederhana dan mudah diperoleh, tetapi media tradisional merupakan kearifan lokal yang tumbuh dan terpelihara secara turun-temurun sejak nenek moyang. Bagi masyarakat Aceh, media-media tradisional seperti tari saman, seudati, dan yang lainnya merupakan warisan leluhur (indatu) yang sangat penting dihargai dan dilestariakan. Tidak hanya untuk kepentingan hiburan, tetapi termasuk untuk membangkitkan gairah keberagamaan (Anwar, 2015).

\section{Metode}

Masyarakat dengan karakteristiknya yang berbeda, tentu membutuhkan pendekatan yang berbeda pula. Konsep ini didasarkan pada realitas sosial, bahwa pada kenyataannya masyarakat sasaran dakwah berwarna-warni. Ini mendorong agar para pendakwah mampu membaca situasi, agar dapat mengadaptasikan metode dakwah yang sesuai. Indikasi ini sangat kuat diisyaratkan oleh Saydina Ali, agar para pendakwah menyesuaikan dakwahnya dengan kadar kemampuan penalaran penerima dakwah. Istilah Effendi (1984), mampu meyelaraskan antara frame of reference (kerangka pemikiran) dengan field of experience (pengalamana lapangan). Bahkan konsep ini juga ditegaskan dalam Al Qur'an surah An Nahl 125, yang memberikan peluang bagi para da'i untuk memilih salah satu diantara tiga metode dakwah yang ada, atau sebaliknya mengkolaborasikan ketiganya. 
Dakwah yang kontributif tidak dapat keluar dari tiga metode yang disebutkan pada surah An Nahl 125. Jika dakwah tidak solutif, bisa jadi metode yang diterapkan tidak tepat. Juga yang paling penting dipahami, bahwa memilih dan menggunakan salah satu metode, berarti sekaligus menyesuaikannya dengan pilihan pesan yang akan disampaikan. Jika berbicara tentang kemiskinan, tentu persoalan kemiskinan tidak dapat diselesaikan dengan ceramah an sich, melainkan harus dicontohkan (maw'izah hasanah) cara mengatasinya. Dengan demikian, metode ini sekaligus menuntut da'i agar memberikan contoh keteladanan. Istilah lainnya da'i harus melakukan dakwah bil hal (pemberdayaan).

Tetapi kenyataannya, bila diamati realitas metode dakwah yang dipraktikkan para pendakwah di Kota Langsa, umumnya masih berkelindan pada metode dakwah bil lisan (ceramah). Para pendakwah berceramah dari masjid ke masjid, majelis taklim, perwiritan, pengajian, dan sebagainya. Metodenya secara umum berceramah, padahal ada masalah mad'u yang tidak dapat diselesaikan dengan ceramah. Kondisi ini terjadi, karena para pendakwah memposisikan dirinya pada zona nyaman sebagai penceramah, bukan sebagai pendakwah. Zona nyaman tersebut kemudian melahirkan sikap keengganan untuk merubah orientasi dakwah dari yang sifatnya konvensional tradisional (ceramah), kepada dakwah yang sifatnya perbedayaan, solutif dan adaptif dengan perkembangan. Maka sangat wajar, kalau para pendakwah sangat jarang turun langsung menyelesaikan persoalan lingkungan kumuh, persoalan kemiskinan, masalah sengketa lahan, kerusakan hutan dan sebagainya.

Bila dimaknai arti dakwah yang dikemukakan syekh Ali Mahfuz (1952), maka pendakwah dipahami sebagai seorang motivator yang dapat membangkitkan gairah keberagamaan. Pendakwah juga seorang motivator yang dapat menggairahkan kepada tindakan kebaikan (al khoir) yang tidak hanya ada di masjid-masjid, perwiritan dan pengajian, tetapi tersedia diberbagai tempat. Pendakwah juga seorang motivator yang dapat menggairahkan semangat pencapaian kebahagiaan yang abadi. Kebahagian yang abadi tidak hanya bersifat eskatologis an sich, tetapi termasuk kebahagiaan dunia juga bahagian dari cita-cita dakwah yang digelorakan Syekh Ali Mahfuz. Untuk bahagia di akhirat, tidak harus miskin dan menderita di dunia. Justeru sebaliknya, kebahagiaan dunia harus diraih untuk mengejar kebahagiaan di akhirat. Jadi teori dakwah Syekh Ali Mahfuz menggambarkan praktik keseimbangan.

Dengan demikian, untuk mewujudkan dakwah yang kontributif, maka tiga metode dakwah yang terdapat pada surah An Nahl, tidak hanya sebagai tawaran bagi para pendakwah. Namun metode tersebut harus dioperasionalkan dalam kegiatan dakwah terhadap seluruh aspek kehidupan masyarakat. Metode dakwah tidak lagi berkelindan pada ceramah an sich. Tetapi metode dakwah harus dirubah orientasinya sesuai kebutuhan masyarakat. Sebagaimana yang dilakukan oleh Rasullah Saw yang mengintegrasikan metode dakwah yang variatif pada setiap praktik dakwahnya. Hal ini perlu dilakukan, agar dakwah tidak kehilangan elan vitalnya.

\section{Tujuan}

Merumuskan dakwah yang kontributif terhadap persoalan masyarakat, tentu tidak terlepas dari tujuan yang diinginkan. Pada satu sisi, merumuskan tujuan dakwah adalah sebagai upaya merubah paradigma, agar para pendakwah jangan sampai berpikir bahwa 
dakwah hanya sekedar menyampaikan ajaran Islam dan melepaskan diri dari jeratan hukum kewajiban berdakwah. Pada sisi lainnya, merumuskan tujuan dakwah merupakan satu upaya untuk merubah sikap dan perilaku masyarakat kepada kesadaran beragama secara benar. Jika masyarakat beragama secara benar, maka tidak akan terjadi pembiaran terhadap persoalan kemiskinan, penindasan, penderitaan, dan sebagainya. Kemuliaan ajaran Islam tersebutlah yang ingin ditanamkan para pendakwah kepada masyarakat sasaran dakwah.

Para pakar secara umum telah menjelaskan bahwa tujuan dakwah adalah untuk meraih kebahagiaan dunia dan akhirat. Tentu tujuan yang demikian masih bersifat makro. Tujuan mikro dakwah penting dilihat sehingga strategi yang dilakukan lebih terukur. Tujuan mikro dakwah misalnya untuk mengetaskan kemiskinan, menumbuhkan kesadaran melestarikan lingkungan, kesadaran terhadap pentingnya kebersihan, kebahagiaan rumah tangga, kebaikan dalam interaksi sosial dan lain sebagainya. Tentu strategi untuk mewujudkan tujuan mikro tersebut berbeda-beda. Itulah sebabnya, peta dakwah sangat penting dalam mewujudkan tujuan dakwah yang diinginkan.

\section{PENUTUP}

Pada akhirnya sangat penting ditegaskan, bahwa memahamai peta dakwah, merupakan satu upaya untuk merumuskan kegiatan dakwah yang kontributif terhadap persoalan mad'u. Tulisan ini berargumen bahwa tidak terjawabnya sebahagian pesoalan masyarakat disebabkan oleh dakwah yang kurang kontributif terhadap persoalan masyarakat. Para pendakwah belum mendasarkan pelaksanaan kegiatan dakwahnya sesuai dengan peta dakwah. Akibatnya, dakwah tidak solutif, dan dakwah tidak lebih dari rutinitas menyampaikan ceramah agama yang tema-temanya berkutat pada persoalan eskatologis dan metodenya monoton.

Membaca peta dakwah, berupa narasi kondisi sosi demografis, sosil kultural, sosio psikologis dan sosio religius masyarakat merupakan modal utama dalam mewujudkan dakwah yang kontributif dalam menjawab persmasalahan masyarakat. Peta dakwah merupakan gambaran potensi masyarakat yang dapat dimanfaatkan untuk mendukung pencapaian tujuan dakwah. Ketidakmampuan membaca atau pengabaian terhadap peta dakwah, akan menyebabkan ketidak berhasilan dalam mewujudkan tujuan dakwah. Itulah sebabnya tulisan ini sangat penting ditampilkan untuk menjadi bahan diskusi bagi para sarjana dan juga aktivis dakwah. Tentu tulisan ini tidak sempurna, sehingga pantas untuk dikritik berdasarkan kajian-kajian akademik dan keilmuan.

\section{DAFTAR PUSTAKA}

Abdullah, A. (2012). Analisis SWOT Dakwah di Indonesia: Upaya Merumuskan Peta Dakwah. MIQOT: Jurnal Ilmu-Ilmu Keislaman, 36(2). https://doi.org/10.30821/miqot.v36i2.125

Achmad, A. (1983). Dakwah Islam dan Perubahan Sosial. Prima Duta.

Anwar, H. (2015). Konteks Sosial Budaya dan Fungsi Dodaidi "Lagu Buaian Anak Aceh": Analisis Sastra Lisan Finnegan. Tesis Universitas Gadjah Mada, Indonesia.

Arifin, A. (2003). Komunikasi Politik: Paradigma, Teori, Aplikasi, Strategi Komunikasi Politik Indonesia. PT. Balai Pustaka. 
Arifin, M. (2004). Psikologi Dakwah Suatu Pengantar. Bumi Aksara.

Aziz, M. A. (2004). Ilmu Dakwah. Prenada Media Group.

Aziz, R. (2015). Urgensi Peta Dakwah. Anida, 14(2). https://doi.org/10.15575/anida.v14i2.845

Badri, M. (2016). Informasi dan komunikasi ( Studi pada Gerakan Desa Membangun ). Jurnal Risalah, 27(2).

Bayanuny, S. M. A. A. F. Al. (2010). Ilmu Dakwah: Prinsip dan Kode Etik Berdakwah Menurut Al Qur'an dan As Sunnah (D. Junaedi (Trans.)). Akademika Pressindo.

Bungin, B. (2003). Analisa Data Penelitian Kualitatif: Pemahaman Filosofis ke Arah Penguasaan Model Aplikasi. PT RajaGrafindo Persada.

Creswell, J. W. (1994). Research Design: Qualitative \& Quantitative Approach. Sage Publication.

Effendy, O. U. (1984). Ilmu Komunikasi Teori dan Praktek. PT. Remaja Rosdakarya.

Effendy, O. U. (2001). Dinamika Komunikasi. PT. Remaja Rosdakarya.

Erickson, F. (2018). The SAGE Handbook of Qualitative Research (N. K. Denzin \& Y. S. Lincoln (Eds.); Fifth Edit). Sage Publications.

Geertz, C. (1973). The Interpretation Of Cultures. Basic Books, Inc., Publishers.

Hariyanto, H. (2020). Relasi Kredibiltas Da'i dan Kebutuhan Mad'u Dalam Mencapai Tujuan Dakwah. AL-IDZAAH: Jurnal Dakwah Dan Komunikasi, 2(01). https://doi.org/10.24127/al-idzaah.v2i01.249

Hasil Wawancara. (2019).

Hemmerling, S. A., Barra, M., Bienn, H. C., Baustian, M. M., Jung, H., Meselhe, E., Wang, Y., \& White, E. (2020). Elevating Local Knowledge Through Participatory Modeling: Active Community Engagement in Restoration Planning in Coastal Louisiana. Journal of Geographical Systems, 22(2). https://doi.org/10.1007/s10109-019-00313-2

Hidayat, K. (1998). Tragedi Raja Midas Moralitas Agama dan Krisis Modernitas. Paramadina.

Holdcroft, B. (2006). What is Religiosity. Catholic Education: A Journal of Inquiry and Practice, 10(1), 89-103.

Huberman, M. B. M. dan A. M. (1992). Analisis Data Kualitatif (T. R. Rohidi (Trans.)). UI Press.

Karim, A., Adeni, A., Fitri, F., Fitri, A. N., Hilmi, M., Fabriar, S. R., \& Rachmawati, F. (2021). Pemetaan untuk Strategi Dakwah di Kota Semarang Menggunakan Pendekatan Data Mining (Mapping for Da'wah Strategy in Semarang City Using Data Mining Approach). Jurnal Dakwah Risalah, 32(1). https://doi.org/10.24014/jdr.v32i1.12549

Katimin, K. (2012). Pertumbuhan dan Perkembangan Parmalim di Sumatera Utara Tahun 1885-Sekarang. Journal Analytica Islamica, 1(2), 196-214.

Kholil, S., Arifinsyah, \& Khoiri, N. (2010). Peta Dakwah Sumatera Utara (M. Simanjuntak $\&$ H. B. Nasution (Eds.)). Perdana Publishing.

Laila. (2015). Eksistensi Media Tradisional Sebagai Media Informasi Publik. Jurnal Penelitian Pers Dan Komunikasi Pembangunan, 19(2). https://doi.org/10.46426/jp2kp.v19i2.28

Langsa, B. P. S. K. (2020). Kota Langsa Dalam Angka. BPS Kota Langsa.

Lincoln, Y. S., \& Guba, E. G. (1985). Naturalistic Inquiry. Sage Publications.

Mahfuz, S. A. (1952). Hidayatul Mursyidin Ila Turuqid Dakwah. Libanon.

Moleong, L. J. (2006). Metode Penelitian Kualitatif. PT. Remaja Rosdakarya.

Mulyana, D. (2004). Metode Penelitian Kualitatif: Paradigma baru Ilmu Komunikasi dan Ilmu Sosial Lainnya. Remaja Rosdakarya. 
Nihayah, N., \& Burhanudin, A. M. (2018). Pemetaan Dakwah Analisis Potensi dan Problematika Dakwah. ORASI: Jurnal Dakwah Dan Komunikasi, 9(1). https://doi.org/10.24235/orasi.v9i1.2962

Pimay, A., \& Savitri, F. M. (2021). Dinamika dakwah Islam di era modern. Jurnal Ilmu Dakwah, 4l(1). https://doi.org/10.21580/jid.v41.1.7847

Rachmadi, F. (1990). Perbandingan Sistem Pers; Analisa Deskriptif Sistem Pers di Berbagai Negara. PT. Gramedia.

Roztocki, N., Soja, P., \& Weistroffer, H. R. (2019). Information Technology for Development The Role of Information and Communication Technologies in Socioeconomic Development: Towards a Multi-dimensional Framework. Information Technology for Development, 25(2), 171-183. https://doi.org/10.1080/02681102.2019.1596654

Siregar, M. (2015). Menyeru Tanpa Hinaan (Upaya Menyemai Dakwah Humanis Pada Masyarakat Kota Langsa yang Pluralis). Jurnal Dakwah, 16(2), 203-229. https://doi.org/10.14421/jd.2015.16202

Siregar, M. (2019). Perencanaan Komunikasi Pemerintah Kota Langsa Dalam Membangun Kota Yang Islami Dan Ramah Lingkungan. Disertasi UIN SU.

Stark, R., \& Glock, C. Y. (1968). American Piety: The Nature of Religious Commitment. University Of California Press.

Sulthon, M. (2003). Menjawab Tantangan Zaman Desain Ilmu Dakwah Kajian Ontologis, Epistimologis, dan Aksiologis. Pustaka Pelajar.

Vavilina, N. D., \& Skalaban, I. A. (2015). Social mapping as a tool for public participation. Regional Research of Russia, 5(1). https://doi.org/10.1134/S2079970515010116

Yakin, S. (2020). Peta Dakwah Kecamatan Sawangan Kota Depok. Dakwah: Jurnal Kajian Dakwah Dan Kemasyarakatan, 24(2). https://doi.org/10.15408/dakwah.v24i2.18341 